8.Joyner, K.L., X.-R. Wang, J.S. Johnston, H.J. Price, and C.G. Williams. 2001. DNA content for Asian pines parallels New World relatives. Can. J. Bot. 79:179-191.

9.Kinlaw, C.S. and D.B. Neale. 1997. Complex gene families in the pine genome. Trends Plant Sci. 2:356-359.

10.Kriebel, H.B. 1985. DNA sequence components of the Pinus strobus nuclear genome. Can. J. For. Res. 15:1-4.

11.Oetting, W.S., H.K. Lee, D.J. Flanders, G.L. Wiesner, T.A. Sellers, and R.A. King. 1995. Linkage analysis with multiplexed short tandem repeat polymorphisms using infrared fluorescence and M13 tailed primers. Genomics 30:450-458.

12.Roy, R., D.L. Steffens, B. Gartside, G.Y. Jang, and J.A. Brumbaugh. 1996. Producing STR locus patterns from bloodstains and other forensic samples using an infrared fluorescent automated DNA sequencer. J. Forensic Sci. 41:418-424

13.Schwengel, D.A., A.E. Jedlicka, E.L. Nanthakumar, J.L. Weber, and R.C. Levitt. 1994. Comparison of fluorescence-based semi-automated genotyping of multiple microsatellite loci with autoradiographic techniques. Genomics 22:46-54.

14.Steffens, D.L., S.L. Sutter, and S.C. Roemer. 1993. An alternate universal forward primer for improved automated DNA sequencing of M13. BioTechniques 15:580-581.

15. Williams, C.G. 1998. QTL mapping in outbred pedigree, p. 81-94. In A.H. Paterson (Ed.), Molecular Dissection of Complex Traits. CRC Press, Boca Raton, FL.

16.Zhou, Y., T. Bui, L.D. Auckland, and C.G. Williams. Undermethylated DNA as a source of microsatellites from a conifer genome. Genome (In Press.)

This work was supported by Department of Energy grant no. DE-FC07-00ID13877, National Science Foundation Bioinstrumentation grant no. NSF DB1-9871390, and Texas Higher Education Coordinating Board grant no. 999902-090. The authors thank Dr. Patricia Klein, Jacques Obert, and Natalie Unruh for technical assistance with the LI-COR automated DNA analyzer at the Borlaug Center for Southern Crop Improvement. Address correspondence to Dr. Claire G. Williams, Faculty of Genetics and Department of Forest Science, Texas A\&M University, College Station, TX 77843-2135, USA.e-mail: claire-williams@tamu.edu

Received 1 August 2001; accepted 18 September 2001.

Yi Zhou, Thomas Bui, Lisa D. Auckland, and Claire G. Williams

Texas A\&M University College Station, TX, USA

\section{Kit-Based, Low-Toxicity Method for Extracting and Purifying Fungal DNA from Ectomycor- rhizal Roots}

\section{BioTechniques 32:52-56 (January 2002)}

Ectomycorrhizal fungi are ecologically and economically important because when they form associations with roots of species such as pines, oaks, and eucalypts, they may increase nutrient and water uptake (15). Functional and taxonomic diversity among the ectomycorrhizal fungi is great and thus, in many studies, it is important to identify individual fungal species. During the past few years, researchers have perfected DNA-based methods for the identification of ectomycorrhizal fungi. In most cases, this involves the extraction and purification of DNA from colonized roots, amplification of fungal genomic DNA, and either analysis of restriction fragments or sequencing (1, $3-5,7,9,10)$.

The extraction of DNA from ectomycorrhizal roots, as commonly published, involves some combination of manual grinding, freezing and thawing, and incubation at elevated temperatures, while purification may involve chloroform or phenol/chloroform extraction of impurities and precipitation of DNA by alcohol $(3,5,7,10)$. The process may take hours to complete, and it requires the use of a fume hood to vent chloroform and phenol vapors. We desired a simple, inexpensive, rapid, and less hazardous method for extracting and purifying readily amplifiable fungal DNA from ectomycorrhizal roots, and a kit-based method seemed ideal. However, as far as we are aware, there are no kits specifically designed to extract and purify fungal DNA from ectomycorrhizal roots. Here, we report on the successful use of a commercially available kit to do this without manual grinding, specialized shaking apparatus, or phenol/chloroform.

The three extraction/purification methods reported here use the UltraClean ${ }^{\mathrm{TM}}$ Microbial DNA Kit (Mo Bio Laboratories, Solana Beach, CA, USA).
The kit was originally designed to extract DNA from solution-cultured microbial cell pellets. It consists of $1.9-\mathrm{mL}$ microcentrifuge extraction tubes containing garnet beads, MicroBead buffer solution, a detergent-based extraction solution (M1), an acetate-based solution to precipitate impurities (M2), a salt solution to cause the DNA to bind to the supplied silica column (M3), an ethanol washing solution (M4), and $10 \mathrm{mM}$ Tris (M5) for DNA elution.

For Method 1, clusters of ectomycorrhizal roots comprising 2-4 root tips were sampled by hand from the fermentation layer of the forest floor from an approximately 65-year-old red pine (Pinus resinosa) plantation located in State College, Centre County, PA, USA. The ectomycorrhizal root clusters were viewed using a dissecting microscope (10-40×) with reflected light to separate them according to morphotype. The clusters of a single morphotype, morphotype $\mathrm{G}$ (unpublished data), were selected. All root clusters were frozen at $-20^{\circ} \mathrm{C}$ before use. Two days later, DNA from two replicate ectomycorrhizal root clusters was extracted and purified. Each root cluster was placed in its own extraction tube. Then, $300 \mu \mathrm{L}$ MicroBead solution were added, followed by $50 \mu \mathrm{L}$ M1 and 50 $\mu \mathrm{L}$ inhibitor removal solution (IRS) (Mo Bio Laboratories). IRS is included in the UltraClean Soil DNA Kit to inactivate the phenolic components of soil organic matter that can inhibit DNA amplification (16). Phenolic compounds are also present in the roots of many ectomycorrhizal trees $(8,13,14$, $17)$, so it was used here. Each extraction tube was heated to $65^{\circ} \mathrm{C}$ for $15 \mathrm{~min}$ in an oven to aid in the extraction. The tubes were then clipped to the vortex adapter (Mo Bio Laboratories) attached to a Vortex Genie 2 Mixer ${ }^{\circledR}$ (Fisher Scientific, Pittsburgh, PA, USA) and agitated at the highest speed for $15 \mathrm{~min}$. The adapter consists of a $14.5-\mathrm{cm}$ diameter plastic plate with 12 plastic clips around the perimeter to hold the tubes. We attached the adapter to the mixer with a strong adhesive, not with the loop and pile tape supplied by the manufacturer. This transferred more of the energy from the mixer to the tubes. A newer version of the adapter that does not require this adhesive step is 
now available from the manufacturer. The extraction tubes were heated a second time for $30 \mathrm{~min}$ at $65^{\circ} \mathrm{C}$ and then centrifuged at $10000 \times g$ for $30 \mathrm{~s}$. Approximately $300 \mu \mathrm{L}$ supernatant from each extraction tube were transferred to new microcentrifuge tubes (supplied with the kit). To each tube, we added $100 \mu \mathrm{L} \mathrm{M} 2$, followed by brief mixing. The tubes were then held at $-20^{\circ} \mathrm{C}$ for 10 min to precipitate contaminants and centrifuged at $10000 \times g$ for $1 \mathrm{~min}$. Supernatant $(450 \mu \mathrm{L})$ from each tube was transferred to a new microcentrifuge tube to which $900 \mu \mathrm{L} \mathrm{M} 3$ were added, and the mixture was shaken briefly. From each tube, $700 \mu \mathrm{L}$ were added to silica columns (supplied with the kit), which were centrifuged at $10000 \times g$ for $30 \mathrm{~s}$, and the liquid was discarded. This process was repeated. The DNA adhering to each column was washed once with $300 \mu \mathrm{L} \mathrm{M} 4$, followed by centrifugation at $10000 \times g$ for $30 \mathrm{~s}$. The wash solution was discarded, and the silica columns were again centrifuged at $10000 \times g$ for $1 \mathrm{~min}$ to remove all ethanol. The DNA was then eluted from each silica column into new microcentrifuge tubes by the addition of $50 \mu \mathrm{L}$ M5 and centrifugation at $10000 \times g$ for $30 \mathrm{~s}$.

We tested the utility of the IRS and heating in the extraction by omitting each of these steps from Method 1 (i.e., No IRS and No Heat methods, respectively). Four days later, clusters of ectomycorrhizal roots comprising 2-3 tips each of morphotype $\mathrm{G}$ were sam pled from the forest floor of the red pine plantation described earlier. Root clusters were kept frozen at $-20^{\circ} \mathrm{C}$ for subsequent use. Two days later, DNA from individual clusters was extracted using the three methods, each with two replications.

The No Heat method was also applied to clusters of ectomycorrhizal roots (2-6 tips/cluster) representing several different morphotypes, including those tentatively categorized as $\mathrm{A}$ (Russula brevipes), B (Cenococcum geophilum), C (Lactarius chrysorheus), $\mathrm{C}^{\prime}$ and D (Tylopilus felleus), and F, G, $\mathrm{H}$, and I (Scleroderma citrinum).

For the three extraction/purification methods, $5 \mu \mathrm{L}$ DNA extract were used in 50- $\mu \mathrm{L}$ amplification reactions similar to those described elsewhere (3-5,7,9, $10)$ but with some modifications. The DNA concentration was variable among the replications of a single morphotype and among morphotypes. Despite this, all extractions yielded amplifiable DNA (see below). We used the primers ITS1F (3) and ITS4 (7) (Operon Technologies, Alameda, CA, USA) at a concentration of $30 \mathrm{pmol} / \mathrm{reaction}(0.6 \mu \mathrm{M})$. We used 1.25 U Taq DNA polymerase (Gene Choice; PGC Scientific, Frederick, MD, USA) in each reaction. The total $\mathrm{MgCl}_{2}$ concentration (including that contained in the proprietary PCR buffer) was 3.0 $\mathrm{mM}$. The concentration of BSA was 0.4 $\mu \mathrm{g} / \mu \mathrm{L}$. BSA is used to improve the efficiency of the DNA amplification in the presence of various amplification inhibitors (11). The dATP, dGTP, dCTP, and dTTP were each added at $20 \mathrm{nmol} /$ reaction ( $0.4 \mathrm{mM}$ each). The DNA am plifications were completed in a Primus 96 Plus peltier thermal cycler (MWGBiotech, Ebersberg, Germany). The lid temperature was $102^{\circ} \mathrm{C}$. The thermal

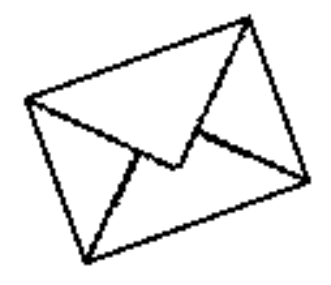

\section{a note from...BioTechniQues about...2001 Ad Hoc Reviewers}

In past years, the editors and staff of BioTechniques acknowledged ad hoc reviewers by publishing all of their names in very small print on many pages. The number of reviewers has now grown to the point that this form of acknowledgment is no longer feasible. All reviewers, including our editorial board members, have played an essential role in the peer-review process. We are indebted to them all for contributing their time and expertise to the critical evaluation of submitted manuscripts. 
cycling program included an initial denaturation step of $95^{\circ} \mathrm{C}$ for $2 \mathrm{~min}$, followed by 40 cycles of denaturation, annealing, and elongation. All denaturations during the 40 cycles occurred at $94^{\circ} \mathrm{C}$ for $40 \mathrm{~s}$, and all elongations occurred at $72^{\circ} \mathrm{C}$ for $40 \mathrm{~s}$. Annealings initially occurred at $62^{\circ} \mathrm{C}$ and dropped $0.5^{\circ} \mathrm{C}$ each cycle until finally reaching $50^{\circ} \mathrm{C}$. This "touchdown" PCR is recom mended as a means to reduce nonspecific annealing of primers and to increase yield $(2,6)$. The final elongation occurred at $72^{\circ} \mathrm{C}$ for $7 \mathrm{~min}$, followed by an indefinite holding period at $8^{\circ} \mathrm{C}$. Negative controls (no DNA template) were used in every experiment to test for the presence of contaminating DNA in the PCR reagents. In no case were PCR products observed in the negative controls (data not shown).

PCR products were electrophoresed in horizontal $0.8 \%$ agarose gels $(4 \mathrm{~mm}$ thick $\times 12 \mathrm{~cm} \times 14 \mathrm{~cm})($ model B-2; Owl Separation Systems, Portsmouth, $\mathrm{NH}$, USA) with approximately $6 \mathrm{~V} / \mathrm{cm}$ applied between electrodes. The 100bp DNA ladder was purchased from New England Biolabs (Beverly, MA, USA). DNA was visualized following staining with ethidium bromide with the EDAS ${ }^{\circledR} 290$ electrophoresis documentation system (Eastman Kodak, Rochester, NY, USA) employing 1-D imaging software, version 3.5.3 (Eastman Kodak).

Method 1 applied to morphotype G ectomycorrhizal root clusters yielded PCR products of just fewer than $800 \mathrm{bp}$ (Figure 1A, lanes 2 and 3). The IRS appeared to be important for the amplification of fungal DNA extracted from the red pine roots [compare the No IRS method (Figure 1B, lanes 2 and 3) with Method 1 (Figure 1B, lanes 4 and 5)]. The roots of pine and other conifers contain condensed tannins and other phenolic compounds $(8,13,14,17)$, some of which are capable of interfering with the PCR (16). BSA added to the PCR mixture may also help to improve the DNA amplification in the presence of such phenolic inhibitors (11).

The heating steps during the extraction process did not appear to be necessary because the No Heat method had a similar yield as Method 1 [compare Method 1 (Figure 1B, lanes 4 and 5) with the No Heat method (Figure 1B, lanes 6 and 7)]. Again, each method resulted in a single product of just fewer than $800 \mathrm{bp}$, but the No Heat method is significantly more rapid than the other methods, requiring approximately 45 min less per set of extractions. For each of the nine root morphotypes extracted with the No Heat method, a single product of variable length was produced (Figure 1C).

We cannot be sure that in every case we extracted and amplified the DNA from ectomycorrhizal fungi. DNA from saprotrophic fungi growing on the surface of ectomycorrhizal roots could also have been extracted. However, if that did happen, a different saprotroph would have to have been amplified from each of the different ectomycorrhiza morphotypes shown in Figure 1C, which seems unlikely. Moreover, four of the nine species shown in Figure 1C have been identified as ectomycorrhizal fungi by terminal restriction fragment length polymorphism (T-RFLP) analysis (12) of both root-tip fungal DNA and DNA from sporocarps of known ectomycorrhizal fungal species (data not shown). Further matches between the root tips and sporocarps will probably be made as we analyze T-RFLP data from sporocarps of more ectomycorrhizal fungal species. Finally, all PCR products from morphotype $\mathrm{G}$ ectomycorrhizal roots (Figure 1, A and B) are of identical length, suggesting further that the chance amplification of DNA from contaminating saprotrophic fungi was not likely.

Jonsson (9) and T. Horton (personal communication) have found that the commonly used method of DNA extraction of Gardes et al. (3) involving freeze/thaw cycles and micropestle grinding may result in the successful amplification of fungal DNA from root tips in $50 \%-95 \%$ of cases. Using the No Heat method on previously frozen roots, we have successfully amplified fungal DNA from ectomycorrhizal roots in 38 of 41 attempts. However, we have failed to extract DNA from un-

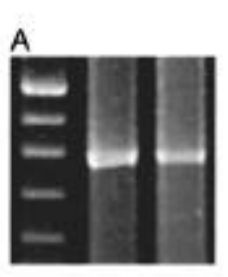

B
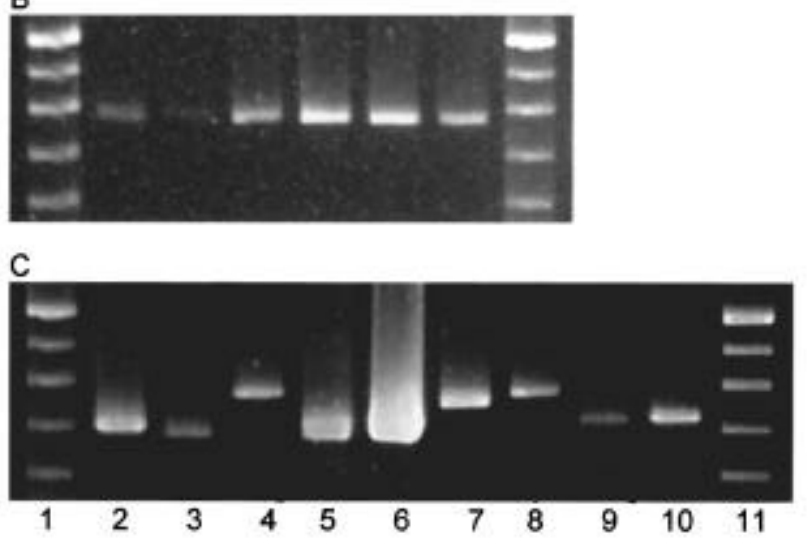

Figure 1. PCR products amplified from fungal DNA extracted from ectomycorrhizal pine roots. (A) Lane 1, 100-bp ladder (from bottom to top, 600, 700, 800, 900, and $1000 \mathrm{bp}$ ) and lanes 2 and 3 , Method 1 applied to morphotype G. (B) Lane 1, 100-bp ladder; lanes 2 and 3, No IRS method applied to morphotype G; lanes 4 and 5, Method 1 applied to morphotype G; lanes 6 and 7, No Heat method applied to morphotype G; and lane 8, 100-bp ladder. (C) Lane 1, 100-bp ladder; lanes 2-10, No Heat method applied to morphotypes A, B, C, C, D, F. G, H, and I, respectively; and lane 11, 100-bp ladder. According to T-RFLP analysis (data not shown), morphotype A corresponds to $R$. brevipes; C, $L$. chrysorheus; D, T. felleus; and I, S. citrinum which are all known to be ectomycorrhizal. Based on morphotype analysis, B is C. geophilum 
frozen roots on numerous occasions.

Our results suggest that the No Heat method is adequate for the routine extraction of fungal DNA from colonized roots. With a single mixture, 12 samples can be easily processed in under $2 \mathrm{~h}$. In contrast, Method 1 would require nearly $3 \mathrm{~h}$. The rapidity and enhanced safety of extraction and purification using the No Heat method over previously published methods stem from three innovations. First, heating, freezing and thawing, and grinding are not necessary. Apparently, the combination of prior freezing (for storage) and the physical disruption of the fungal cells with garnet beads during the extraction appears to efficiently extract fungal DNA. A common laboratory vortex mixer is sufficient to generate the force for the physical disruption of the fungal cells. Specialized shaking apparatus is unnecessary. Second, the use of the IRS in the extraction mixture effectively counteracts the inhibition of PCR by phenolic compounds that are inherent in the roots of many ectomycorrhizal trees. This permits a simpler and safer purification process. Third, purification is further simplified by using silica columns for binding and washing the DNA. Thus, potentially hazardous chloroform or phenol/chloroform extractions of impurities and precipitation of DNA by alcohol are unnecessary.

\section{REFERENCES}

1.Armstrong, J.L., N.L. Fowles, and P.T. Rygiewicz. 1989. Restriction fragment length polymorphisms distinguish ectomycorrhizal fungi. Plant Soil 116:1-7.

2.Don, R.H., P.T. Cox, B.J. Wainwright, K. Baker, and J.S. Mattick. 1992. "Touchdown" PCR to circumvent spurious priming during gene amplification. Nucleic Acids Res. 19:4008.

3.Gardes, M. and T.D. Bruns. 1993. ITS primers with enhanced specificity for basidiomycetes - application to the identification of mycorrhizae and rusts. Mol. Ecol. 2:113-118.

4.Gardes, M. and T.D. Bruns. 1996. ITS-RFLP matching for identification of fungi, p. 177186. In J.P. Clapp (Ed.), Methods in Molecular Biology, vol. 50. Species Diagnostics Protocols: PCR and other Nucleic Acid Methods. Humana Press, Totowa, NJ.

5.Gardes, M., T.J. White, J.A. Fortin, T.D. Bruns, and J. Taylor. 1991. Identification of indigenous and introduced symbiotic fungi in ectomycorrhizae by amplification of nuclear and mitochondrial ribosomal DNA. Can. J. Bot. 69:180-190.

6.Hecker, K.H. and K.H. Roux. 1996. High and low annealing temperatures increase both specificity and yield in touchdown and stepdown PCR. BioTechniques 20:478-485.

7.Henrion, B., F. Le Tacon, and F. Martin. 1992. Rapid identification of genetic variation of ectomycorrhizal fungi by amplification of ribosomal RNA genes. New Phytol. 122:289298.

8.Hillis, W.E. and N. Ishikura. 1969. The extractives of the mycorrhizas and roots of Pinus radiata and Pseudotsuga menziesii. Aust. J. Biol. Sci. 22:1425-1436.

9.Jonsson, L. 1998. Community structure of ectomycorrhizal fungi in Swedish boreal forests [dissertation]. Uppsala (Sweden): Swedish University of Agricultural Sciences. $130 \mathrm{p}$. Available from: Department of Forest Mycology and Pathology, Swedish University of Agricultural Sciences, Uppsala, Sweden.

10.Kårén, O., N. Högberg, A. Dahlberg, L. Jonsson, and J.-E. Hylund. 1997. Inter- and intraspecific variation in the ITS region of rDNA of ectomycorrhizal fungi in Fennoscandia as detected by endonuclease analysis. New Phytol. 136:313-325.

11.Kreader, C.A. 1996. Relief of amplification inhibition in PCR with bovine serum albumin or T4 gene 32 protein. Appl. Environ. Microbiol. 62:1102-1106.

12.Lukow, T., P.F. Dunfield, and W. Liesack. 2000. Use of the T-RFLP technique to assess spatial and temporal changes in the bacterial community structure within an agricultural soil planted with transgenic and non-transgenic potato plants. FEMS Microbiol. Ecol. 32:241247.

13.Münzenberger, B., J. Heilemann, D. Strack, I. Kottke, and F. Oberwinkler. 1990. Phenolics of mycorrhizas and non-mycorrhizal roots of Norway spruce. Planta 182:142-148.

14.Piché, Y., J.A. Fortin, and J.G. Lafontaine. 1981. Cytoplasmic phenols and polysaccharides in ectomycorrhizal and non-mycorrhizal short roots of pine. New Phytol. 88:695-703.

15.Smith, S.E. and D.J. Read. 1997. Mycorrhiza Symbiosis, 2nd ed. Academic Press, San Diego.

16.Tebbe, C.C. and W. Vahjen. 1993. Interference of humic acids and DNA extracted directly from soil in detection and transformation of recombinant DNA from bacteria and yeast. Appl. Environ. Microbiol. 59:2657-2665.

17.Weiss, M., S. Mikolajewski, H. Peipp, U. Schmitt, J. Schmidt, V. Wray, and D. Strack. 1997. Tissue-specific and development-dependent accumulation of phenylpropanoids in larch mycorrhizas. Plant Physiol. 114:15-27.

We are grateful for the funding provided by the A.W. Mellon Foundation and the US Department of Agriculture. We also thank Dr. Rick Hart of Mo Bio Laboratories for his many helpful suggestions in the development of the technique and the three anonymous reviewers for suggestions on an earlier version of this manuscript. Address correspondence to Dr. Roger T. Koide, The Pennsylvania State University, University Park, PA 16802,USA.e-mail: rkoide@psu.edu
Received 29 August 2001; accepted 10 October 2001.

\author{
Roger T. Koide and \\ Ian A. Dickie \\ The Pennsylvania State \\ University \\ University Park, PA, USA
}

\section{Rescue of Completed but Unread HIV-1 Antibody ELISA Microplates by Freezing}

\author{
BioTechniques 32:56-60 (January 2002)
}

Freezing and thawing (FT) of biological specimens before or after the analysis of various analytes is a common laboratory practice. In general, biological analytes present in specimens are usually quite refractory to FT. For example, in the area of infectious disease testing, studies describing multiple FT cycles indicated no deleterious consequences on subsequent analytical analysis for nucleic acid of hepatitis $\mathrm{C}$ virus (10) or of HIV-1 (5-7), for infectivity of varicella-zoster (2) or of HIV1 (3), or for HIV-1 antibody reactivity in ELISAs $(4,11)$.

Routine laboratory testing for the detection of HIV-1 antibodies is performed with ELISAs (9). This type of testing is generally completed within $3-4 \mathrm{~h}$ and is conducive to efficiently testing large numbers of specimens at one time. However, an interruption in any step of the ELISA due to such circumstances as power outage would typically require repeating the entire group of specimens from the start of the ELISA procedure. In such unusual circumstances, several steps of the ELISA procedure, including washing, could be performed manually without the aid of automated equipment. The mainte- 